\title{
Catenin Family Protein
}

National Cancer Institute

\section{Source}

National Cancer Institute. Catenin Family Protein. NCI Thesaurus. Code C118480.

A family of adaptor proteins that bind to cadherin proteins and promote the association of cadherins with the actin cytoskeleton. Catenins play a role in the formation of adherens junctions, the regulation of cell proliferation and the modulation of Wnt signaling pathways. 